\title{
Genome
}

\section{Development and characterization of species-diagnostic ISSR and SCAR DNA markers differentiating red maple (Acer rubrum) and silver maple (A. saccharinum)}

\begin{tabular}{|r|l|}
\hline Journal: & Genome \\
\hline Manuscript ID & gen-2019-0037.R1 \\
\hline Manuscript Type: & Article \\
\hline Author: & 06-May-2019 \\
\hline Complete List of Authors: & $\begin{array}{l}\text { Boyd, Meagan; Laurentian University, Biology } \\
\text { Panoyan, Maryanne; Laurentian University, Biology } \\
\text { Michael, Paul; Laurentian University } \\
\text { Nkongolo, Kabwe; Laurentian University }\end{array}$ \\
\hline Keyword: & Acer rubrum, Acer freemanii, ISSR, SCAR markers, Acer saccharinum \\
\hline $\begin{array}{r}\text { Is the invited manuscript for } \\
\text { consideration in a Special } \\
\text { Issue? : }\end{array}$ & Not applicable (regular submission) \\
\hline
\end{tabular}

\section{SCHOLARONE Manuscripts}


Development and characterization of species-diagnostic ISSR and SCAR DNA markers differentiating red maple (Acer rubrum) and silver maple (A. saccharinum)

Meagan Boyd ${ }^{1}$, Mary Anne Panoyan ${ }^{1}$, Paul Michael ${ }^{2}$, and Kabwe K. Nkongolo ${ }^{1,2, *}$

Boyd, Meagan; Panoyan, Maryanne; Michael, Paul; Nkongolo, Kabwe

${ }^{1}$ Department of Biology, and ${ }^{2}$ Biomolecular Sciences Program, Laurentian

University, Sudbury, Ontario, Canada, P3E 2C6

${ }^{*}$ Corresponding author: Kabwe K. Nkongolo1

knkongolo@laurentian.ca 


\begin{abstract}
Red maple (Acer rubrum) and silver maple (A. saccharinum) are sister species that readily hybridize in nature. No genetic or barcoding markers have been tested in these species. The main objective of the present study is to develop and characterize molecular markers distinguishing $A$. rubrum and $A$. saccharinum and to validate the hybridity of $A$. freemanii derived from their crossings using the ISSR marker system. Thirteen A. rubrum and seven A. saccharinum populations were used. Four ISSR primers including ISSR 5, ISSR 8, ISSR 10, and ISSR UBC 825 were selected to amplify genomic DNA from the two species and their hybrids. Each primer generated at least one species-diagnostic ISSR markers for a total of six. Analysis of $A$. fremanii collected from North Dakota (USA) confirmed that the genotypes screened were true hybrids between $A$. rubrum and $A$. saccharinum. These markers were cloned and sequenced. Successful sequences were converted to SCAR markers using specifically designed primers. Overall, the developed diagnostic and specific ISSR and SCAR markers are useful in the certification of these two maple species and their hybrids. They can be used in tracking the introgression of $A$. rubrum and A. saccharinum DNA in other hybrid trees/populations.
\end{abstract}

Key words: Acer rubrum; Acer saccharinum; Acer freemanii; ISSR; SCAR markers: Speciesdiagnostic DNA markers. 


\section{Introduction}

Acer rubrum, A. saccharinum, and A. freemanii

The most well-known species of maples, include, silver maple (Acer saccharinum) and red maple (Acer rubrum). These two species intercross readily in nature producing a hybrid species, Freemans maple (Acer freemanii)

A. rubrum can be both a late and early successional species in many forests, where it dominates the understory and mid-canopy of many oak, and pine, in northern hardwood forests (Abrams 1998). There is high genetic diversity in this species for physiological and growth characteristics, including, cold hardiness, time of seed germination, time of budset, growth rate, stem form, fall color, as well as, drought tolerance and leaf morphology. Hence, it can adapt and survive better than other species under less water, nutrients, and light conditions (Abrams 1998). Their high genetic diversity also contributes to the widespread ecological success of the species. It reaches sexual maturity at a young age, and produces a large number of seeds with little germination requirements that are readily dispersed at maturity (Abrams 1998).

A. saccharinum is very similar to A. rubrum except that its leaves turn pale yellow or brown, not red, in the fall. These trees are normally found in moist areas, often along streams. They are native to eastern and central North America, in the United States and Canada (Burns and Honkala 1990). Their seedlings can survive long periods of flooding, allowing them to outcompete other species for growing space. A. saccharinum are often used as ornamental trees due to their early rapid growth and appealing appearance (Burns and Honkala 1990).

A. rubrum and $A$. saccharinum bloom at the same time of the season, thus providing natural hybridization between the two species. The hybrids, known as $A$. freemanii, are a good 
intermediate of the parents in respect to leaf characteristics. Its growth is much more rapid than that of the A. rubrum seedlings, but slower than that of $A$. saccharinum (Burns and Honkala 1990).

The distinction among the three species A. rubrum, A. saccharinum, and S. freemanii based on morphological characteristics can be difficult especially at the seedling stage. This is in part because environmental factors also play a key role in phenotypes of plants growing in different ecological conditions.

Molecular markers are more reliable in identification of species. Phylogenetic relationships among Acer species confirmed that A. saccharinum and A. rubrum are sister species based on cpDNA sequences ( $\mathrm{Li}$ et al. 2006). But the number of phyogenetic studies including these species is limited and information on their sequence is lacking.

There are several molecular markers that can be used for species identification. No genetic or barcoding markers have been tested in these species. Inter simple sequence repeats (ISSR) is a cost effective system that have been used in previous investigations. Emerging in 1994, ISSRs are DNA fragments in which the sequence is between two adjacent, identical microsatellites that are in opposite orientation (Sarwat 2012). They were first used by Zietkiewicz et al. (1994) on cultivated plant species. This marker system provides a great and reliable technique especially when studying natural populations. They are fast, affordable, economical, and, they are also easy to use (Muchugi et al. 2008). Another advantage to using the reliable ISSR primers is that no prior knowledge of the genome is required. The main disadvantage of ISSR is that it is dominant in nature and therefore, has less specificity and may lead to lower reproducibility due to the poor quality of genomic DNA; however, it is known that ISSR is still highly reproducible (Sarwat 2012). For example, they have been successfully used 
in detection of somaclonal variation, genetic stability (Lata et al. 2010), gene tagging (Ammiraju et al. 2001), identification of cultivar (Nagaraju et al. 2002), identification of hybrids (Lin et al. 2010), phylogenetic studies (Paris et al. 2003), genetic relatedness (Rajwade et al. 2010), as well as, in assessing production quality (Wu et al. 2010). It has been reported that ISSRs are more polymorphic and informative compared to restriction fragment length polymorphisms (RFLP) and amplified fragment length polymorphism (AFLP) (Sarwat 2012). Sequence characterized amplified regions (SCAR) markers developed from ISSR and other molecular markers are very sensitive and highly reliable (Nkongolo et al. 2005). They can aid in solving any ambiguities in identifying targeted species.

The main objective of the present study is to develop and characterize ISSR and SCAR markers distinguishing $A$. rubrum and $A$. saccharinum and to validate the hybridity of $A$. freemanii.

\section{Materials and Methods}

\section{Plant sampling and processing}

Certified seeds of Acer rubrum from different sources were provided by the National Tree Seed Centre (Natural Resources Canada, Fredericton). They include seedlots 200010442, 20011024, 20011031, 20021067, 20081002, and 20011037. For A. saccharinum, certified seeds (lot 1823857) originating from Kentucky were provided by Shieffield seed Co. Inc (New York). Additional A. rubrum and A. saccharinum samples were collected as leaves from different sites in the Northern Ontario in ecological areas specific for each species. For A. rubrum, the sampling sites include Kelly Lake, Azilda, Capreol, Kingsway, St. Charles, Wahnapitae Sudbury Hydro, and Falconbridge. For A. sacharimum, leaves were collected from trees growing on four sites 
including Laurentian University campus, Laurentian conservation area, Madison Avenue, and Westmount (New Sudbury). On each site, 10 trees were selected. About 10 to 20 leaves from each tree were collected. Seeds of $A$. rubrum and $A$. saccharinum from different provenances in Ontario, New Brunswick, and Quebec were also used for this marker development and validation (Table 1). Seeds of A. freemanii, collected in North Dakota from controlled crossings (Lot number 1821454), were provided by Sheffield Seed Company, New York, USA. All the seeds were germinated in "Petawawa" germination boxes and seedlings were grown in a deep tray with soil. The leaves were wrapped with aluminum paper, then submerged into liquid nitrogen, and stored at approximately $-20^{\circ} \mathrm{C}$ until DNA extraction.

\section{DNA Extraction}

Genomic DNA was extracted following the protocol described by Nkongolo et al. (2005). One gram of the frozen plant material was grinded into a fine powder in liquid nitrogen, using a mortar and a pestle. Each sample was suspended in $15 \mathrm{~mL}$ of CTAB buffer (pH 8.0 with 1\% PVP and $0.02 \% \beta$-mercaptoethanol) and incubated in a water bath at $60^{\circ} \mathrm{C}$ for 45 minutes. Once an emulsion was attained, an equal amount of chloroform: octanol mix (24:1) was added to each tube, balanced, and then vigorously inverted for 3 minutes. The samples were then centrifuged at $12,500 \mathrm{rpm}$ for 15 minutes at room temperature $\left(25^{\circ} \mathrm{C}\right)$. The aqueous layer of each sample was then transferred to their respectively labelled tubes. An equal amount of chloroform:octanol mix was again added to each tube, and once emulsion was attained, the samples were centrifuged at the same speed and temperature as previously mentioned for 5 minutes. The aqueous layer was transferred to new tubes, with equal volume of chloroform: octanol mix added, then, inverted, balanced, and centrifuged at 12,500 rpm for 5 minutes at room temperature. The supernatant was transferred to fresh tubes, where $10 \mathrm{mLs}$ of isopropanol had been added. The tubes were 
gently inverted and balanced, then placed in the centrifuge at $6,500 \mathrm{rpm}$ for 25 minutes at $4^{\circ} \mathrm{C}$. The tubes were then drained with a Pasteur pipette, and $5 \mathrm{~mL}$ of $70 \%$ ethanol was added, and the solution was incubated at room temperature for 5 minutes. The tubes were then drained for a second time, and the bubbles were carefully vacuumed up. Once all the ethanol was evaporated, the DNA pellet that had formed was suspended in about 200-500 $\mu \mathrm{L}$ (depending on the size of the pellet) of 1xTE (Tris-EDTA) buffer. The tubes with the resuspended pellet of DNA were stored at $4^{\circ} \mathrm{C}$ until the following day. For $A$. freemanii, genomic DNA was extracted from embryos because of poor seed germination following the QIAGEN DNeasy protocol

\section{Amplification of ISSR markers}

Initially, fifteen ISSR primers were tested for preliminary amplification of A. rubrum, $A$. saccharinum, and A. freemanii. PCR analysis was carried out following the procedure described by Nkongolo et al. (2005), Theriault et al. (2014), and Moarefi et al. (2018). Each PCR reaction was performed using a total of $25 \mu \mathrm{l}$ volumes containing a master mix of $11.4 \mu \mathrm{L}$ distilled water, $2.5 \mu \mathrm{L} \mathrm{MgSO}_{4}, 2.1 \mu \mathrm{L} 10 \mathrm{x}$ buffer $0.5 \mu \mathrm{L}$ of dNTPs (equal parts dTTP, dATP, dCTP, dGTP), 0.5 $\mu \mathrm{L}$ of ISSR primer, a Taq mix of $3.475 \mu \mathrm{L}$ distilled water, $0.4 \mu \mathrm{L} \mathrm{10x}$ buffer, and $0.125 \mu \mathrm{L}$ Taq polymerase (Applied Biosystems) and $4 \mu \mathrm{L}$ standardized DNA. For each primer, a negative control reaction was included where $\mathrm{ddH} 2 \mathrm{O}$ was added instead of DNA. All samples were covered with one drop of mineral oil to prevent evaporation and amplified with the Eppendorf Mastercycler gradient. The program was set to a hot start of 5 minutes at $95{ }^{\circ} \mathrm{C}$ followed by 2 minutes at $85^{\circ} \mathrm{C}$ after which the Taq mix was added. This was followed by 42 cycles of 1.5 minutes at $95{ }^{\circ} \mathrm{C}, 2$ minutes at $55^{\circ} \mathrm{C}$ and one minute of $72{ }^{\circ} \mathrm{C}$, and a final extension of 7 minutes at $72{ }^{\circ} \mathrm{C}$. Samples were then removed from the thermocycler and placed in the $-20{ }^{\circ} \mathrm{C}$ freezer until further analysis. All PCR products were loaded into $2 \%$ agarose gel in $0.5 \mathrm{X}$ Tris-Borate- 
EDTA (TBE) buffer. After the DNA samples were amplified, they were separated for analysis on a $2 \%$ agarose gel in $0.5 \mathrm{x}$ TBE with ethidium bromide and run at $3.14 \mathrm{~V} / \mathrm{cm}$.

Five $\mu \mathrm{L}$ of $1 \mathrm{x}$ loading buffer were added to the PCR products and $10 \mu \mathrm{L}$ of this solution were loaded into the wells of the gel. The gel was run as described above, documented with the BioRad ChemiDoc XRS system and analyzed with Image Lab Software. Only the ISSR primers which gave consistent profiles across the populations and also those that appeared to have diagnostic markers were selected for further analysis.

\section{Cloning and sequencing}

Species-diagnostic ISSR bands were extracted from agarose gels using the QIAquick Gel Extraction Kit (Qiagen) and quantified using the Saran wrap method (Sambrook et al. 1989; Vaillancourt et al. 2008). They were cloned into the pGEM-T® Easy Vector System II (Promega, Madison, WI). Escherichia coli JM 109 competent cells were transformed with the recombinant vectors and were then plated onto LB/ampicillin/IPTG/X-Gal plates. Positive colonies were determined by blue/white screening. Plasmids from randomly selected white colonies were extracted using the lysis by alkali protocol from Sambrook et al. (1989) with few modifications. The vectors containing the fragments of the correct size were sequenced at University of British Columbia Sequencing and Bioinformatics Consortium. The sequenced data were analyzed using ABI Prism sequencing analysis version 3.3 (PE Biosystems). For each sequence, a pair of target primers flanking the insert region was designed and synthesized by Life Technologies Inc. 


\section{Results}

Sequences of the 15 primers tested along with their GC content are described in Table 2. Four of these primers screened generated consistent banding profiles. They include ISSR 5, ISSR 8, ISSR 10, and ISSR UBC 825. A band that was present in all A. rubrum samples and absent in all the $A$. saccharinum was considered a diagnostic marker for A. rubrum. Likewise, an $A$. saccharinum diagnostic marker is present in all the samples from this species and absent in $A$. rubrum samples. For ISSR 5, a diagnostic DNA marker was found for $A$. saccharinum at $950 \mathrm{bp}$, and at $490 \mathrm{bp}$ for $A$. rubrum. For ISSR 8, a diagnostic marker of 2,000 bp was identified in $A$. saccharinum. For ISSR 10, one A. saccharinum DNA marker of 1,400 bp and one A. rubrum DNA band of 1, 900 bp were detected (Table 3). Finally, ISSR 825 generated a 500 bp band diagnostic for A. rubrum. Each species-diagnostic marker was validated three times. Some species-diagnostic ISRR markers are illustrated in Figures 1, 2, 1S, and 2S.

The same four primers, ISSR 5, ISSR 8, ISSR 10, and ISSR UBC 825, were used to confirm the hybridity of 40 genotypes from an A. freemanii population. Both the A. rubrum and A. saccharinum DNA diagnostic markers were present in A. rubrum $x$ A. saccharinum (A. freemanii) genotypes screened. PCR amplifications for A. freemanii are depicted in Figures 2 and $2 \mathrm{~S}$.

To assess the species-specificity of ISSR markers, pairs of primers flanking cloned ISSR fragments were designed and used to target theses sequences in genomic DNA of $A$. rubrum and A. saccharinum in more sensitive PCR assays. The main characteristics of designed primers are described in Table 4. Amplification of A. saccharinum DNA with the Ac-Sac-UBC-825 primer pair generated a strong species-specific SCAR since it was not identified in any A. rubrum that we screened (Fig. 3). The consensus sequence of this marker has been registered in the National 
Center for Biotechnology Information (NCBI) Genbank in the Bethesda (Maryland, USA) under the accession number MK287621 (Fig. 4). BLAST search results reveal no matching sequence for this marker in any database. Amplification of A. rubrum DNA with the Ac-R-UBC-825 primer pair generated faint bands.

\section{Discussion}

The reliability of the ISSR marker system has been confirmed in different investigations. Prevost and Wilkinson (1999) reported that ISSR can generate more polymorphisms than RFLP and RAPD, thus providing reliable and promising information. ISSR revealed clear, distinct, and sufficient information needed to characterize tree populations in a study reported by Nudin et al. (2017). Balasaravanan et al. (2006) successfully used ISSR marker system to distinguish six eucalyptus species of seaweed, as many of their characteristics show similarities. Salis et al.(2017) demonstrated the usefulness of ISSR molecular marker technique in distinguishing between species of citrus rootstocks.

Species-specific wheat (Triticum aestivum) and rye (Secale cereale) ISSR markers have been described by Vaillancourt et al. (2008). Nkongolo et al. (2005, 2012) used ISSR and RAPD marker systems to certify the identity of spruce (Picea spp.) trees. They were able to develop species-diagnostic markers, and validate that interior spruce trees analyzed were true $P$. glauca and $P$. engelmannii hybrids. Interestingly, they demonstrated that one of the declared $P$. glauca $x$ P. mariana hybrids in many studies based on morphological characteristics was not a hybrid rather a true $P$. glauca.

In the present study, ISSR primers used generated a high level of polymorphic loci. The data were highly reproducible and provided strong support for the use of ISSR for hardwood 
species differentiation. Although the comparative analysis of these two species (A. rubrum and A. sacharum) is lacking in the literature, one study demonstrated using haplotypes that $A$. rubrum and A. saccharinum had a distinct phylogeographic group (Saeki et al. 2011). Krahl et al. (1993), demonstrated using RAPD that A. rubrum has unique sequences that differentiate it from other maple species.

Skepner and Krane (1998) compared black maple (A. nigrum) and sugar maple ( $A$. sacharum) using RAPD system. They showed that although classified as different species, $A$. nigrum and A. saccharum, have similar RAPD marker profiles. These results could be because the primers used might not target differential regions of the genomes rather that the lack of genetic differences between the targeted species.

Although all the species-diagnostic markers described in the present study are useful, the development of a SCAR marker provided a more practical tool for screening a large number of samples. Two species-diagnostic ISSR markers were successfully converted to a speciesspecific SCAR marker, but only one sequence was deposited in the NCBI genebank as it was very clean. There exists a couple of reasons that could explain why diagnostic markers such as some of those developed in the present study once converted to a SCAR marker are not speciesspecific. The appearance of a band in one species and its absence in another could result from competitions among DNA fragments during amplification (Nkongolo et al. 2003; Lorenz 2012). In fact, amplified products which are complementary to each other are stabilized by internal base pairing that could prevent amplification by out-competing the binding of random primers (Nkongolo et al. 2003; Lorenz 2012); this is the most serious problem that leads to the incorrect interpretation of results. Formation of secondary structures including hair pin, by DNA fragments could also have a critical impact on the amplification. Such structures, if formed, 
might hinder the amplification of potential target regions by making the primer binding site inaccessible to primer and /or the polymerase. However, the frequency of heteroduplex formation of bands with homologous sequences is very low. Since the SCAR system is a more sensitive technique, the above problems will not interfere with the amplification of sequences even if they are present in a low copy number.

The markers developed in the present study will certainly be a reliable tool for ecological studies. Saeki et al. (2011) reported based on cpDNA analysis that Acer rubrum showed greater haplotype diversity than A. scaharinum because of its greater geographic range, and ecological, and morphological variation. Their study provides evidence of introgression where these two species are sympatric, which led to an increase in haplotype diversity in both species. The diagnostics ISSR markers and species-species SCAR markers developed in this study would be very useful in validating the hybridity of populations and trees in sympatric congeneric species. They can be also suitable for screening Acer seedlings in nurseries in a revegetation program to make sure that the right genotypes are planted in the appropriate ecological niches.

Moreover, the identification of hybrids between A. rubrum and A. saccharinum (Freeman maples) has been very difficult. Because of a high level of morphological variation within both parent species, and the lack of knowledge of the particular parent trees involved in the cross, only trained botanists and horticulturists, are able to classify putative hybrids in some stands (Santamour 1993). The development of these species diagnostic markers is also relevant because of the new wave of interest in freeman maple as potential superior trees for urban planting. 
The high variability observed in both species can be in part ascribed to the existing cytological variations. Although recent cytological studies are lacking, it is well established that A. saccharinum is tetraploid $(2 \mathrm{n}=4 \mathrm{x}=42)$ while A. rubrum is hexaploid $(2 \mathrm{n}=6 \mathrm{x}=78)$ and octoploid $(2 \mathrm{n}=8 \mathrm{x}=104)$ (Santamour 1965). Aneuploid genotypes have been reported in some stands for both species (Santamour 1965). The chromosome number in Freeman maples is highly variable because of significant differences between the two parental species for chromosome number. The molecular markers developed in this study will certainly be the most cost effective approach in certifying Freeman trees in mixt stand. But Genomic fluorescent in situ hybridization (GISH) will be the best approach to determining chromosome composition for Freeman tree maples (Nkongolo et al. 2009).

\section{Conclusion}

In the present species, four ISSR markers generated strong and reproducible ISSR markers in A. rubrum, A. saccharinum, and A. freemanii. The species-diagnostic and specific ISSR markers developed were successfully used to certify the validity of the A. rubrum $x A$. saccharinum hybrids commonly known as A. freemanii. These markers were converted to SCAR markers using specifically designed primers flanking the marker sequences. SCAR markers derived from A. saccharinum and A. rubrum were developed and characterized and can be a very reliable tool in ascertaining or tracking the presence of these maple DNA in a tree or population. 


\section{Acknowledgement}

This study was supported by the Natural Sciences and Engineering Council of Canada (NSERC) (Grant \# RGPIN/5323-2014).

\section{Conflict of interest}

Authors declare that they have no conflict of interest.

\section{Compliance with ethical standards}

This article does not contain any studies with human subjects or animals performed by any of the authors. 


\section{References}

Abrams, M.D. 1998. The Red Maple Paradox. Bioscience 48(5): 355-364. [American Institute of Biological Sciences, Oxford University Press]. doi:10.2307/1313374.

Ammiraju, J.S.S., Dholakia, B.B., Santra, D.K., Singh, H., Lagu, M.D., Tamhankar, S.A., Dhaliwal, H.S., Rao, V.S., Gupta, V.S., and Ranjekar, P.K. 2001. Identification of inter simple sequence repeat (ISSR) markers associated with seed size in wheat. Theor. Appl. Genet. 102(5): 726-732. doi:10.1007/s001220051703.

Balasaravanan, T., Chezhian, P., Kamalakannan, R. Yasodha, R., Varghese, M., Gurumurthi , K. and Ghosh, M. 2006. Identification of Species-Diagnostic ISSR Markers for Six Eucalyptus Species. Silvae Genet. 55 (3): 119-122

Burns, R., and Honkala, B. 1990. Silvics of North America Vol. 2 Hardwoods. U.S. Department of Agriculture, Washington, D. C.

Krahl, K.H., Dirr, M.A., Halward, T.M., Kochert, G.D., and Randle, W.M. 1993. Use of SinglePrimer DNA Amplifications for the Identification of Red Maple (Acer rubrum L.) Cultivars. J. Environ. Hortic. 11(2): 89-92. Horticultural Research Institute. doi:10.24266/0738-289811.2.89.

Lata, H., Chandra, S., Techen, N., Khan, I.A., and ElSohly, M.A. 2010. Assessment of the Genetic Stability of Micropropagated Plants of Cannabis sativa by ISSR Markers. Planta Med 76(01): 97-100. doi:10.1055/s-0029-1185945.

Li, J., Yue, J., and Shoup, S. 2006. Phylogenetics of acer (aceroideae, sapindaceae) based on nucleotide sequences of two chloroplast non-coding regions. Harvard Pap. Bot. v. 11(no. 1): pp. 101-115. doi:10.3100/1043-4534(2006)11[101:POAASB]2.0.CO;2.

Lin, X.C., Lou, Y.F., Liu, J., Peng, J.S., Liao, G.L., and Fang, W. 2010. Crossbreeding of Phyllostachys species (Poaceae) and identification of their hybrids using ISSR markers. Genet. Mol. Res. 9(3): 1398-1404. doi:10.4238/vo19-3gmr855.

Lorenz, T.C. 2012. Polymerase Chain Reaction: Basic Protocol Plus Troubleshooting and Optimization Strategies. JoVE (63): e3998. MyJoVE Corp. doi:doi:10.3791/3998.

Moarefi, N., Michael, P., Beckett P., Nkongolo, K.K. 2018.Identification of Molecular Markers Differentiating Betula papyrifera and B. pumila Populations from Northern Ontario (Canada). Am. J. Environ. Sci. 14 (5): 246.256.

Muchugi, A., Kadu, C., Kindt, R., Kipruto, H., Lemurt, S., Olale, K., Nyadoi, P., Dawson, I., and Jamnadas, R. 2008. Molecular markers for tropical trees: a practical guide to principles and procedures. Edited byI. Dawson and R. Jamnadass. World Agroforestry Centre, Nairobi. 
Nagaraju, J., Kathirvel, M., Kumar, R.R., Siddiq, E.A., and Hasnain, S.E. 2002. Genetic analysis of traditional and evolved Basmati and non-Basmati rice varieties by using fluorescencebased ISSR-PCR and SSR markers. Proc. Natl. Acad. Sci. U. S. A. 99(9): 5836-5841. The National Academy of Sciences. doi:10.1073/pnas.042099099.

Narendrula, R. and Nkongolo, K.K. 2012. Genetic Variation in Picea mariana $\times$ P. rubens Hybrid Populations Assessed with ISSR and RAPD Markers. Am. J. Plant Sci. 3: 731-737

Nkongolo, K.K., Deverno, L., and Michael, P. 2003. Genetic validation and characterization of RAPD markers differentiating black and red spruces: molecular certification of spruce trees and hybrids. Plant Syst. Evol. 236(3-4): 151.

Nkongolo, K.K., Haley, S.D., Kim, N.S., Michael, P., Fedak, G., Quick, J.S., and Peairs, F.B. 2009. Molecular cytogenetic and agronomic characterization of advanced generations of wheat $\times$ triticale hybrids resistant to Diuraphis noxia (Mordvilko): application of GISH and microsatellite markers. Genome 52(4): 353-360. NRC Research Press. doi:10.1139/G09010 .

Nkongolo, K.K., Michael, P., and Demers, T. 2005. Application of ISSR, RAPD, and cytological markers to the certification of Picea mariana, $P$. glauca, and $P$. engelmannii trees, and their putative hybrids. Genome 48(2): 302-311. Department of Biological Sciences, Laurentian University, Sudbury, ON, Canada. knkongolo@laurentian.ca.doi:10.1139/g04-118.

Nudin, N.F.H., Ali, A.M., Ngah, N., Mazlan, N.Z., Mat, N., Ghani, M.N.A., Alias, N., Zakaria, A.J., and Jahan, M.S. 2017. ISSR marker-assisted genetic diversity analysis of Dioscorea hispida and selection of the best variety for sustainable production. C. R. Biol. 340(8): 359-366. doi:10.1016/j.crvi.2017.08.003.

Paris, H.S., Yonash, N., Portnoy, V., Mozes-Daube, N., Tzuri, G., and Katzir, N. 2003. Assessment of genetic relationships in Cucurbita pepo (Cucurbitaceae) using DNA markers. Theor. Appl. Genet. 106(6): 971-978. doi:10.1007/s00122-002-1157-0.

Prevost, A., and Wilkinson, M.J. 1999. A new system of comparing PCR primers applied to ISSR fingerprinting of potato cultivars. Theor. Appl. Genet. 98(1): 107-112. doi: $10.1007 / \mathrm{s} 001220051046$.

Saeki, I., Dick, C.W., Barnes, B. V, and Murakami, N. 2011. Comparative phylogeography of red maple (Acer rubrum L.) and silver maple (Acer saccharinum L.): impacts of habitat specialization, hybridization and glacial history. J. Biogeogr. 38(5): 992-1005. John Wiley \& Sons, Ltd (10.1111). doi:10.1111/j.1365-2699.2010.02462.x.

Salis, C., Papadakis, I.E., Kintzios, S., and Hagidimitriou, M. 2017. In vitro propagation and assessment of genetic relationships of citrus rootstocks using ISSR molecular markers. Not. Bot. Horti Agrobot. Cluj-Napoca 45(2): 383-391. doi:10.15835/nbha45210900. 
Sambrook, J., Fritsch, E.F., and Maniatis, T. 1989. Molecular cloning: a laboratory manual. Cold Springs Harbor Laboratory, Long Island, New York.

Santamour, F.S. 1965. Cytological Studies in Red and Silver Maples and their Hybrids. Bull. Torrey Bot. Club 92(2): 127-134. Torrey Botanical Society. doi:10.2307/2483933.

Santamour, F.S. 1993. Freeman Maple — Illusion and Truth. J. Arboric. 19(July): 195-200.

Sarwat, M. 2012. ISSR: A Reliable and Cost-Effective Technique for Detection of DNA Polymorphism BT - Plant DNA Fingerprinting and Barcoding: Methods and Protocols. Edited by N.J. Sucher, J.R. Hennell, and M.C. Carles. Humana Press, Totowa, NJ. pp. 103121. doi:10.1007/978-1-61779-609-8_9.

Skepner, A.P., and Krane, D.E. 1998. RAPD reveals genetic similarity of Acer saccharum and Acer nigrum. Heredity (Edinb). 80(4): 422-428. doi:10.1046/j.1365-2540.1998.00312.x.

Theriault, G., Nkongolo, K.K. Narendrula, R., Beckett, P. 2013. Molecular and ecological characterization of plant populations from limed and metal-contaminated sites in Northern Ontario (Canada): ISSR analysis of white birch (Betula papyrifera) populations. Chem. Ecol. 29 (7): 573585

Vaillancourt, A., Nkongolo, K.K., Michael, P., and Mehes, M. 2008. Identification, characterization, and chromosome locations of rye and wheat specific ISSR and SCAR markers useful for breeding purposes. Euphytica 159: 297-306.

Zietkiewicz, E., Rafalski, A., and Labuda, D. 1994. Genome fingerprinting by simple sequence repeat (SSR)-anchored polymerase chain reaction amplification. Genomics 20(2): 176-183. doi:10.1006/geno.1994.1151. 


\section{Figure caption}

Figure 1. ISSR amplification pattern of Acer rubrum and Acer saccharinum DNA with primer ISSR 10. Lanes 1 and 40 contained 1-kb plus DNA ladder; lanes 2-21, Acer saccharinum; Lanes 22-38, Acer rubrum. The arrows indicate species -diagnostic ISSR markers for A. rubrum and $A$. saccharinum.

Figure 2. ISSR amplification pattern of Acer freemanii DNA with primer ISSR 8. Lane 1 contained 1-kb plus DNA ladder; lanes 2 and 3, Acer saccharinum and Acer rubrum respectively. Lanes $4-9$, Acer freemanii. The arrow shows the presence of $A$. saccharinum diagonstic marker in A. freemannii.

Figure 3. PCR amplification of Acer saccharinum and Acer rubrum with Ac-Sach UBS 825 (forward and reverse) primers. Lane 1 contained 1-kb plus DNA ladder, lanes 2-11 contain Acer saccharinum and 12-21 contain Acer rubrum respectively, lane 22 is a no template control. The arrow indicates the SCAR marker in A. saccharinum. Note the absence of bands in Acer rubrum (Lanes 12 to 22 ).

Figure 4. Consensus sequence of an Ac- Sac -UBC 825 ISSR marker (680 bp) specific for Acer saccharinum.

Figure 1S. ISSR amplification patterns of Acer rubrum and Acer saccharinum DNA with primer ISSR 825. Lane 1 contained 1-kb plus DNA ladder; lanes 2-21, Acer saccharinum; Lanes 22-40, Acer rubrum. The arrows indicate species-diagnostic markers for A. saccharinum.

Figure 2S. ISSR amplification pattern of Acer freemanii DNA with primer ISSR 10. Lane 1 contained 1-kb plus DNA ladder, lanes 2 and 3, Acer saccharinum and Acer rubrum respectively. Lanes 4-9, Acer freemanii. The arrows indicate the presence of A. rubrum diagnostic marker in A. freemanii. 
Table 1. List of provenances of tree species tested for the presence of the UBC 825 Acer saccharinum and A. rubrum diagnostic/ specific ISSR and SCAR markers.

\begin{tabular}{|c|c|c|c|}
\hline Species & Provenance & $\begin{array}{l}A . \\
\text { saccharinum } \\
\text { diagnostic } \\
\text { /specific UBC } \\
\text { 825 ISSR and } \\
\text { SCAR marker } \\
\end{array}$ & $\begin{array}{l}\text { A. rubrum } \\
\text { diagnostic/specific } \\
\text { UBC } 825 \text { ISSR } \\
\text { and SCAR } \\
\text { marker }\end{array}$ \\
\hline \multirow{14}{*}{ Acer rubrum } & Spencer Settlement, NB, CAN & Absent & Present \\
\hline & Acadia Research Forest, NB, CAN & Absent & Present \\
\hline & Larry Brook, NB, CAN & Absent & Present \\
\hline & Rooth, NB, CAN & Absent & Present \\
\hline & Oxford, NS, CAN & Absent & Present \\
\hline & Cold brook, NB & Absent & Present \\
\hline & Daisy Lake, Sudbury, ON, CAN & Absent & Present \\
\hline & Laurentian, Sudbury, ON, CAN & Absent & Present \\
\hline & Wahnapitae, ON, CAN & Absent & Present \\
\hline & Kukagami, ON, CAN & Absent & Present \\
\hline & Falconbridge, ON, CAN & Absent & Present \\
\hline & St. Charles, ON, CAN & Absent & Present \\
\hline & Onaping Falls, ON, CAN & Absent & Present \\
\hline & Capreol, ON, CAN & Absent & Present \\
\hline \multirow[t]{10}{*}{ Acer saccharinum } & Laurentian Conservation, ON, CAN & Present & Absent \\
\hline & Madison Av-Sudbury, ON, CAN & Present & Absent \\
\hline & Westmount, Av. -Sudbury, ON, CAN & Present & Absent \\
\hline & Nairn Centre, ON, CAN & Present & Absent \\
\hline & Backus Wood, ON, CAN & Present & Absent \\
\hline & Montreal Botanical Garden, QC, CAN & Present & Absent \\
\hline & La Vallée-du-Richelieu, Otterburn & Present & Absent \\
\hline & Park & & \\
\hline & Montérégie, QC, CAN & & \\
\hline & Kentucky, USA & Present & Absent \\
\hline
\end{tabular}

$\mathrm{CAN}=$ Canada; $\mathrm{NB}=$ New Brunswick; ON = Ontario; $\mathrm{QC}=$ Quebec. 
Table 2. Sequence of ISSR primers used to amplify Acer rubrum and Acer saccharinum DNA

\begin{tabular}{|c|c|c|c|}
\hline Primer & Sequence $\left(5^{\prime}-3^{\prime}\right)$ & G/C content $(\%)$ & $\begin{array}{l}\text { Annealing } \\
\text { temperature }\left({ }^{\circ} \mathrm{C}\right)\end{array}$ \\
\hline ISSR 1 & $(\mathrm{AG})_{8} \mathrm{RG}$ & 53 & 55 \\
\hline ISSR 2 & $(\mathrm{TC})_{8} \mathrm{YC}$ & 50 & 55 \\
\hline ISSR 3 & $(\mathrm{GAC})_{4} \mathrm{G}$ & 69 & 55 \\
\hline ISSR 4 & $(\mathrm{CGT})_{4} \mathrm{C}$ & 69 & 55 \\
\hline ISSR 5 & $(\mathrm{ACG})_{4} \mathrm{AC}$ & 64 & 55 \\
\hline ISSR 6 & $(\mathrm{TTG})_{5} \mathrm{CB}$ & 39 & 55 \\
\hline ISSR 7 & $(\mathrm{AGG})_{5} \mathrm{GY}$ & 65 & 55 \\
\hline ISSR 8 & $(\mathrm{AGAT})_{5} \mathrm{GY}$ & 27 & 55 \\
\hline ISSR 9 & $(\mathrm{GATC})_{3} \mathrm{GC}$ & 57 & 55 \\
\hline ISSR 10 & $(\mathrm{CTT})_{5}(\mathrm{CCT})_{6} \mathrm{CT}$ & 51 & 55 \\
\hline ISSR HB 12 & $(\mathrm{CAC})_{3} \mathrm{GC}$ & 73 & 55 \\
\hline UBC 823 & $(\mathrm{TC})_{8} \mathrm{C}$ & 52 & 55 \\
\hline UBC 825 & $(\mathrm{AC})_{8} \mathrm{~T}$ & 47 & 55 \\
\hline 835 & $(\mathrm{AG})_{8} \mathrm{YC}$ & 50 & 55 \\
\hline 844 & $(\mathrm{CT})_{8} \mathrm{RC}$ & 53 & 55 \\
\hline
\end{tabular}


Table 3. Species-diagnostic markers identified in Acer rubrum and A. saccharinum

\begin{tabular}{lll}
\hline Primers & \multicolumn{2}{c}{ Species-diagnostic marker size (bp) } \\
\hline & $\underline{\text { Acer rubrum }}$ & $\frac{\text { Acer saccharinum }}{10}$ \\
ISSR 5 & 450 & 950 \\
ISSR 8 & - & 2000 \\
ISSR 10 & 1900 & 1400 \\
ISSR UBC 825 & 500 & - \\
\hline
\end{tabular}


Table 4. Sequences and characterization of designed pairs of primers A. saccharinum and $A$. rubrum diagnostic markers

\begin{tabular}{|c|c|c|c|c|}
\hline Primer Name & Primer Sequence (5'-3') & $\mathrm{Tm}$ & $\begin{array}{l}\text { Targeted } \\
\text { Fragment } \\
\text { (bp) }\end{array}$ & Species Specificity \\
\hline $\begin{array}{l}\text { Ac-Sac- } \\
\text { UBC } 825 \mathrm{~F}\end{array}$ & TTATGGAAACCTGGGAGCTG & $54^{\circ} \mathrm{C}$ & 489 & Acer saccharinum \\
\hline $\begin{array}{l}\text { Ac-Sac- } \\
\text { UBC } 825 \text { R }\end{array}$ & CATCGAATCTTCGCCATTGT & $54^{\circ} \mathrm{C}$ & & \\
\hline $\begin{array}{l}\text { Ac-R- } \\
\text { UBC } 825 \mathrm{~F}\end{array}$ & TTCATTGCTTTGTGCCTCTATG & $54^{\circ} \mathrm{C}$ & 215 & Acer rubrum \\
\hline $\begin{array}{l}\text { Ac-R- } \\
\text { UBC } 825 R\end{array}$ & AGCCAGAAGAACAGCCCAGT & $58^{\circ} \mathrm{C}$ & & \\
\hline
\end{tabular}

AC-Sac-UBC 825 and Ac-R-UBC 825 represent designed primers targeting A. sacharimum and A. rubrum diagnostic marker, respectively to generate SCAR markers. 


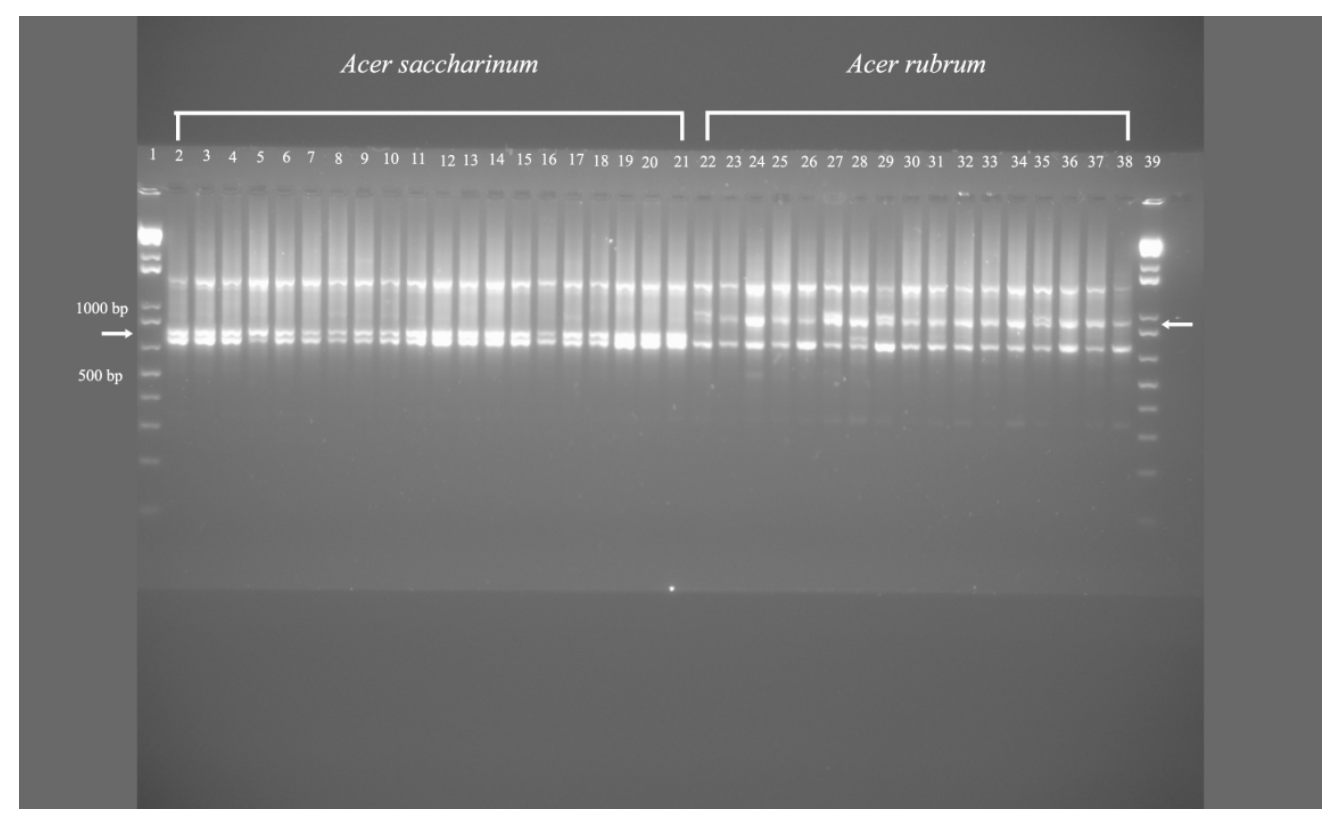

$170 \times 103 \mathrm{~mm}(300 \times 300$ DPI $)$ 


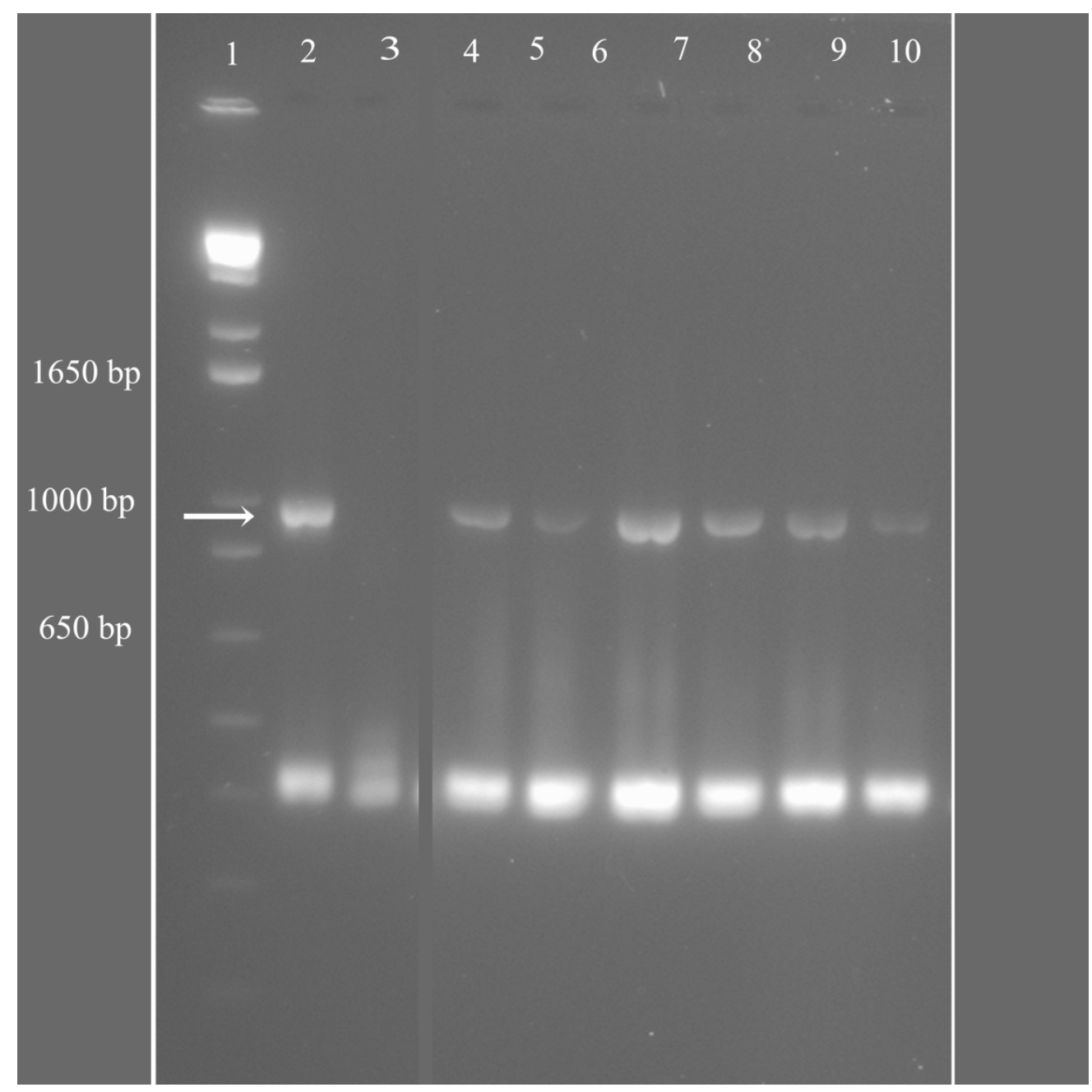

199x199mm (300 x 300 DPI) 


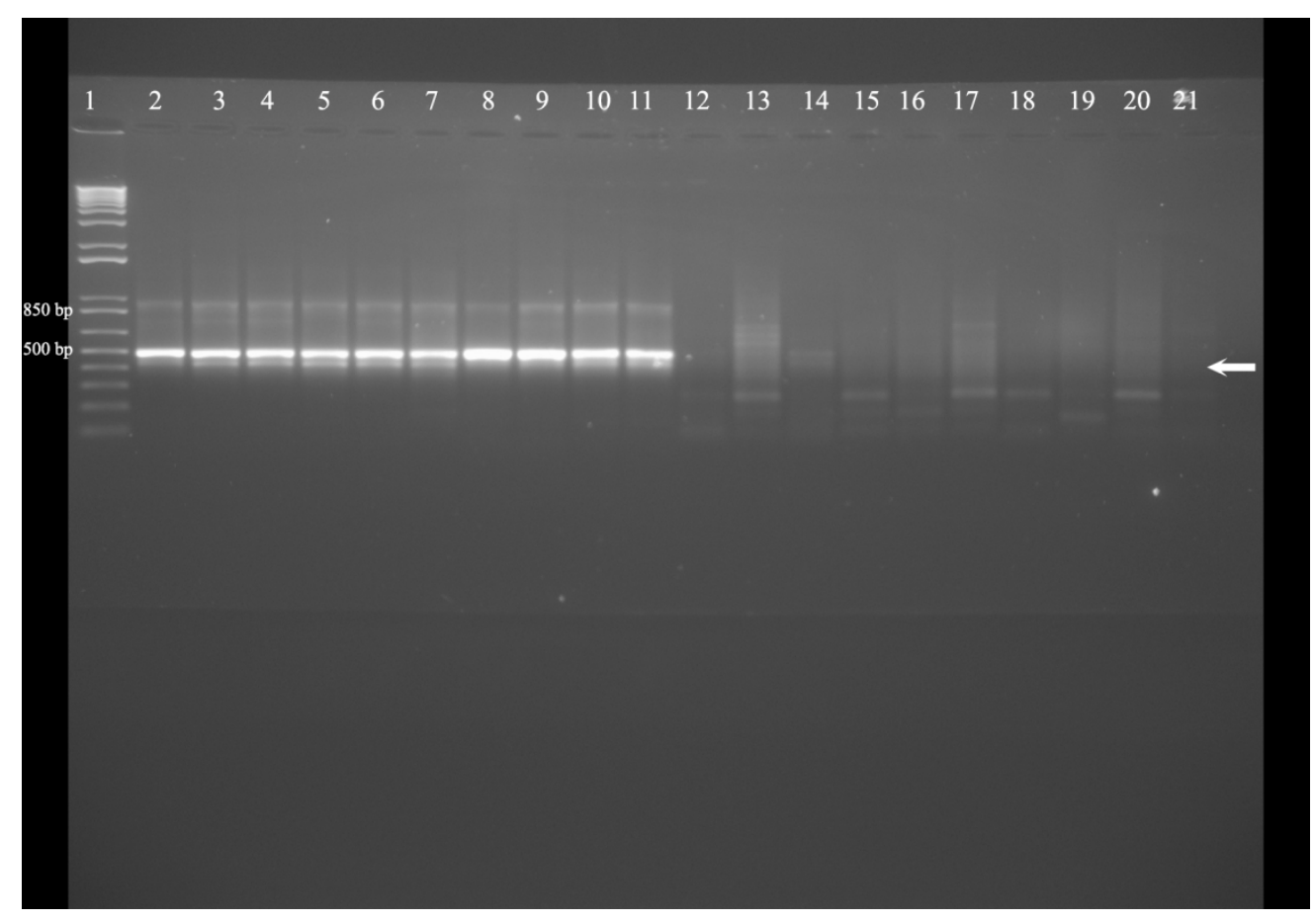

$150 \times 103 \mathrm{~mm}(300 \times 300 \mathrm{DPI})$ 


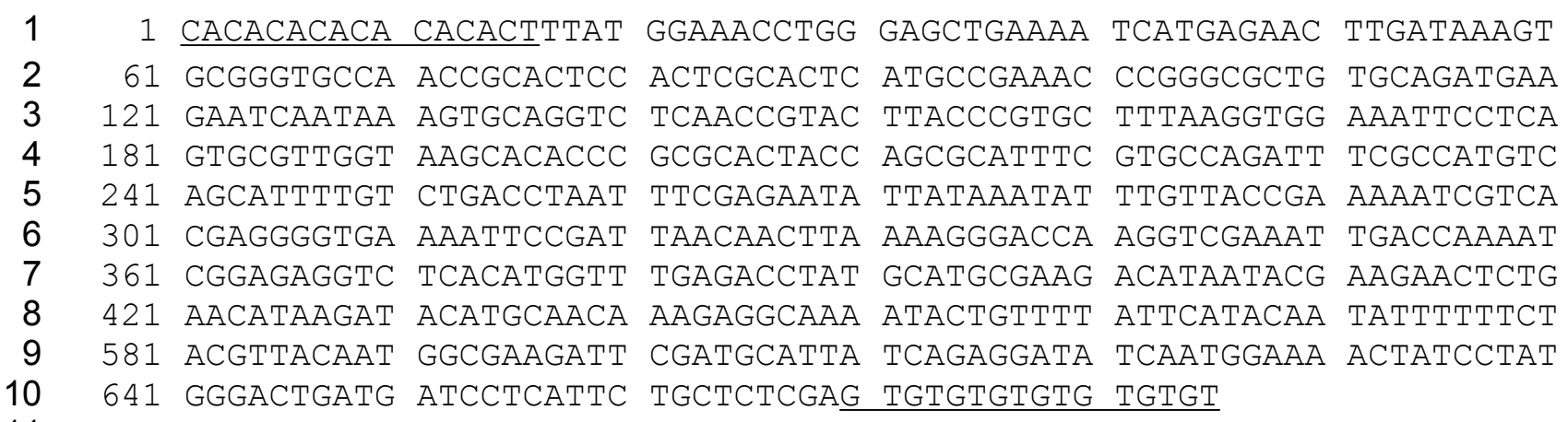

12 Figure 4. Consensus sequence of an Ac- Sac -UBC 825 SCAR marker (680 bp) specific for Acer 13 saccharinum.

14

15 